\title{
Letter to the Editor: Resolution of the Presence of Multiple Forms of the Cyclic Nucleotide Phosphodiesterases (PDE) in Normal and Reye's Syndrome Liver
}

\author{
ELLEN S. KANG \\ Department of Pediatrics, University of Tennessee Center for the Health Sciences, Memphis, Tennessee, USA
}

The published literature cites the presence of alterations of a number of enzymes in the liver of Reye's syndrome subjects $(2,3$, $9,11,12)$. It is, indeed, highly unlikely that each of these alterations is the consequence of a separate defect. Rather, as pointed out by Mitchell (Pediatr. Res., 13: 945 (1979).), these alterations are likely to be mediated through a common regulatory defect. Because the cyclic nucleotides are involved in the regulation of a wide range of metabolic processes, many of which appear to be involved in this disorder as pointed out by us earlier (6), the status of the enzymes which determine their intracellular concentrations is relevant to our understanding of the pathophysiology of this disease.

Table 1. Initial velocity: cyclic AMP PDE of a human liver homogenate

\begin{tabular}{cc}
\hline Substrate concentration $10^{-6} \mathrm{M}$ & $\begin{array}{c}\text { nmoles converted/mg protein/ } \\
\text { min }\end{array}$ \\
\hline 0.153 & 0.026 \\
0.200 & 0.035 \\
0.25 & 0.037 \\
0.33 & 0.037 \\
0.50 & 0.058 \\
1 & 0.095 \\
2 & 0.188 \\
$10^{1}$ & 0.709 \\
$20^{1}$ & 1.02 \\
$50^{1}$ & 2.73 \\
$75^{1}$ & 3.05 \\
$100^{1}$ & 4.63 \\
$150^{1}$ & 8.22 \\
$200^{1}$ & 6.65 \\
$500^{1}$ & 7.64 \\
1000 & \\
1500 & 12.50 \\
\hline
\end{tabular}

${ }^{1}$ Values used by Mitchell.

The Michaelis constants were derived by the Lineweaver-Burk method obtaining the intercepts of the slopes by linear regression analysis (8). The figure could not accommodate all the points used in our analysis by virtue of the wide range of concentrations used. Because Mitchell only used the points of the S-V curve, it necessarily incorporated only those points we used for determining the kinetic constants for the high $\mathrm{Km}$ enzyme. We agree that there is only one form of PDE by the data used by Mitchell. The reciprocals of the upper inset figure would have provided values for the other form, the low $\mathrm{Km}$ PDE. The raw $\mathrm{S}$ and $\mathrm{V}$ values used for the particular study represented by Figure 4 are presented in
Table 1. The technique used by Mitchell to analyze our data magnifies the variables resulting from translation of numerical data into a figurative representation necessarily involving at least two interpretors, the investigator and the artist.

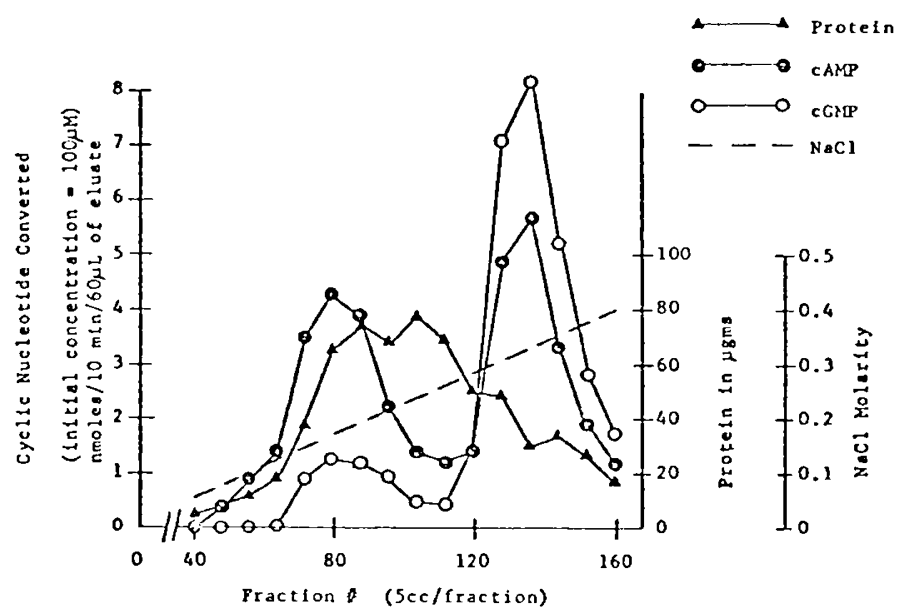

Fig. 1.

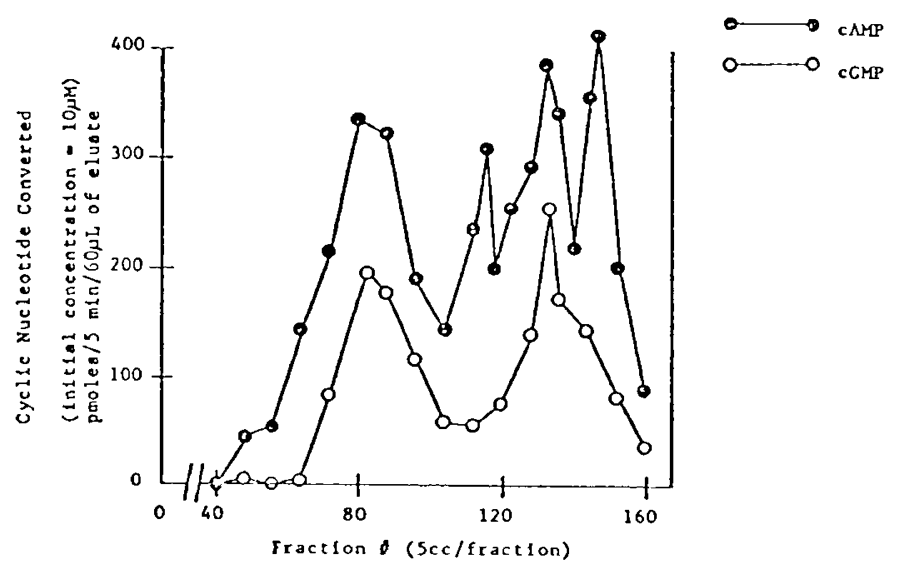

Fig. 2.

Thompson and Appelman (13), in the paper cited by Mitchell, found only one PDE in the liver of the rat. Subsequent reports from these (10) and other workers (1) including one on human liver (4), indicate the presence of multiple forms which can be 
resolved by kinetic analysis as well as by separation by physical and chemical means $(1,5)$.

The point made by Mitchell regarding the need to monitor the contribution of one form to the other is well taken, particularly for the low $\mathrm{Km}$ form of PDE where the contributions of the high $\mathrm{Km}$ form could be substantial. However, in our study, $\mathrm{Km}$ differences were found with the high Km cyclic AMP PDE. With this form, the contributions of the low $\mathrm{Km}$ enzymes would surely be negligible especially because the $\mathrm{V}_{\max }$ for the low $\mathrm{Km}$ form is two orders of magnitude lower than the high $\mathrm{Km}$ PDE.

It should be emphasized that the difference in cyclic AMP Km's found at high substrate concentrations, although statistically significant $(P<0.025,>0.010)$, may not hold when sample size is increased or where the individual molecular forms are separately analyzed. The data presented were obtained from a $30,000 \times \mathrm{g}$ spun homogenate after dialysis to remove endogenous cyclic nucleotides. There are many modulators of PDE activity, not all of which are dialyzable $(5,7)$.

Recently, we have examined control and Reye's liver after homogenization in water or $20 \mathrm{mM}$ Tris- $\mathrm{HCl}$, centrifugation at 30,000 or $100,000 \times g$ and separation by DEAE chromatography with and without EGTA. Figures 1 and 2 are representative of our findings on human liver after homogenization in water and centrifugation at $30,000 \times g$, using a linear $\mathrm{NaCl}$ gradient $(0-0.5$ M). At $100 \mu \mathrm{M}$ substrate concentration, two peaks of activity are found whereas at $10 \mu \mathrm{M}$, two cyclic GMP peaks and four cyclic AMP peaks are found. Centrifugation at $100,000 \times g$ as well as exposure to EGTA result in pattern changes which are currently under analysis. Thus, extension of our studies indicates the presence of multiple forms of PDE in the liver of patients with Reye's syndrome as well as control subjects. Whether the observed statistical difference reported earlier in crude preparations is reflected in these better resolved forms is under investigation currently.
REFERENCES AND NOTES

1. Amer, M. S. and Kreighbaum, W. E.: Cyclic nucleotide phosphodiesterases: properties, activators, inhibitors, structure-activity relationships, and possible role in drug development. J. Pharmaceut. Sci., 64: I (1975).

2. Brown, T., Brown, H., Lansky, L., and Hug, G.: Carbamyl phosphate synthetase and ornithine transcarbamylase in liver of Reye's syndrome. N. Engl. J. Med. 291: 797 (1974).

3. Greene, H. L., Wilson, F. A., Glick, A. D., Dunn, G. D., and Kilroy, A. W.: Hepatic ATP concentrations and glycolytic enzyme activities in Reye's syndrome. J. Pediatr. 89: 777 (1976).

4. Hidaka, H., Yamaki, T., Ochiai, Y., Asano, T., and Yamake, H.: Cyclic 3':5'nucleotide phosphodiesterase determined in various human tissues by DEAEcellulose chromatography. Biochem. Biophys. Acta, 484: 398 (1977).

5. Kakiuchi, S., Yamazaki, R. Teshima, Y. Uenishi, K., and Miyamoto, E. Multiple cyclic nucleotide phosphodiesterase activities from rat tissues and occurrence of a calcium-plus-magnesium-ion-dependent phosphodiesterase and its protein activator. Biochem. J., 146: 109 (1975).

6. Kang, E. S., Chiang. M. H., Kang, A. H., and Ellsworth, D. L.: Evidence of a transient disturbance of cyclic $3^{\prime}, 5^{\prime}$-adenosine monophosphate metabolism in adipose tissue in Reye's syndrome. In: J. D. Pollack: Reye's Syndrome, p. 261 (Grune \& Stratton, New York, 1974).

7. Klee. C. B., and Krinks, M. H.: Purification of cyclic 3',5'-nucleotide phosphodiesterase inhibitory protein by affinity chromatography on activator protein coupled to sepharose. Biochem., 17: 120 (1978).

8. Lineweaver, H., and Burk, D.: The determination of enzyme dissociation constants. J. Am. Chem. Soc., 56: 658 (1934).

9. Robinson, B. H., Gall, D. G., and Cut7., E.: Deficient activity of hepatic pyruvate dehydrogenase and pyruvate carboxylase in Reye's syndrome. Pediatr. Res. 11: 279 (1977).

10. Russell, T. R.. Terasaki, W. L., and Appleman, M. M.: Separate phosphodiesterases for the hydrolysis of cyclic adenosine $3^{\prime}-5^{\prime}$ monophosphate and cyclic guanosine 3'-5'-monophosphate in rat liver. J. Biol. Chem., 248: 1334, (1973).

11. Sinatra, F., Yoshida, T., Applebaum. M., Mason, W., Hoogenraad, N., and Sunshine, P.: Abnormalities of carbamyl phosphate synthetase and ornithine transcarbamylase in liver of patients with Reye's syndrome. Pediatr. Res., 9: 829 (1975).

12. Thaler, M. M., Hoogenraad, N. J., and Boswell, M.: Reye's syndrome due to a novel protein-tolerant variant of ornithine-transcarbamylase deficiency. Lancet, 2: 438 (1974).

13. Thompson, W. J., and Appleman, M. M.: Characterization of cyclic nucleotide phosphodiesterases of rat tissues. J. Biol. Chem., 246: 3145 (1971). 